\title{
The Distinction between Burkitt Lymphoma and Diffuse Large B-Cell Lymphoma with c-myc Rearrangement
}

\author{
Naoya Nakamura, M.D., Hirokazu Nakamine, M.D., Jun-ichi Tamaru, M.D., Shigeo Nakamura, M.D., \\ Tadashi Yoshino, M.D., Kouichi Ohshima, M.D., Masafumi Abe, M.D. \\ Department of Pathology, Fukushima Medical University School of Medicine (NN, MA), Japan; \\ Department of Clinical Laboratory Medicine, Wakayama Medical University School of Medicine (HN), \\ Wakayama; Department of Pathology, Saitama Medical Center, Saitama Medical School (J-IT), Saitama; \\ Department of Pathology and Genetics, Aichi Cancer Center Hospital, Nagoya (SN); Department of \\ Pathology, School of Medicine, Okayama University (TY), Okayama; and Department of Pathology, School \\ of Medicine, Fukuoka University (KO), Fukuoka, Japan
}

To compare immunophenotypic and molecular features between Burkitt lymphoma (BL) and diffuse large B-cell lymphoma (DLBCL) with c-myc rearrangements $\left(c-m y c^{\mathrm{R}}\right.$ DLBCL), we analyzed 18 cases of B-cell non-Hodgkin's lymphoma with $c-m y c^{R}$ that were confirmed by chromosomal and/or Southern blotting analyses. The cases were histologically classified into 10 BLs and five DLBCLs. The remaining three cases could not be classified because of suboptimal quality of the surgical materials. BLs were from five adults and five children, whereas all DLBCLs were from adults. BLs were positive for $\mathrm{CD20}$ (10/10 cases examined), $\operatorname{CD10}(9 /$ $10)$, Bcl-2 (1/9), and Bcl-6 (10/10), whereas they) were negative for $\mathrm{CD3}(0 / 10)$ and $\mathrm{EBV}(0 / 8)$, by Epstein-Barr virus (EBV) EBER-1 RNA in situ hybridization. $\mathrm{c}-M y c^{\mathrm{R}}$ DLBCLs were positive for $\mathrm{CD20}$ (5/5), CD10 (2/5), Bcl-2 (3/4), and Bcl-6 (4/4), whereas none of them were positive for $\mathrm{CD} 3$ and EBV. A mean of MIB-1 index (MIB-1 ${ }^{+}$cells/neoplastic cells, \%) of BLs $(\mathbf{9 8 . 1 \% )}$ was higher than that of c-myc ${ }^{\mathrm{R}}$ DLBCLs $(66.3 \% ; P<.0001)$. Somatic mutation of immunoglobulin heavy-chain gene variable region (VH gene) in BLs (four cases) ranged from 0.7 to $4.9 \%$ with an average value of $2.3 \%$, whereas those in DLBCLs (three cases) from 8.2 to $32.0 \%$ with an average value of $17.0 \%$. It is, therefore, concluded that a growth fraction of nearly $100 \%$, as well as a monotonous proliferation of medium-sized cells and $c-m y c^{R}$, should be of value in the diagnosis

Copyright (C) 2002 by The United States and Canadian Academy of Pathology, Inc.

VOL. 15, NO. 7, P. 771, 2002 Printed in the U.S.A.

Date of acceptance: April 10, 2002.

Address reprint requests to: Naoya Nakamura, M.D. Ph.D., Department of Pathology, Fukushima Medical University School of Medicine, 1-Hikarigaoka, Fukushima-shi, 960-1295, Japan; e-mail: nao@fmu.ac.jp; fax: 81-245-48-4488.

DOI: $10.1097 / 01 . M P .0000019577 .73786 .64$ of $B L$, which is probably different from $c-m y c^{R} D L-$ $\mathrm{BCL}$. In addition, $\mathrm{CDIO}^{+}, \mathrm{Bcl}-2^{-}$, and low frequency of mutation of the VH gene could be helpful for the histologic distinction of BL from $\left(c-m y c^{\mathrm{R}}\right)$ DLBCL.

KEY WORDS: Burkitt lymphoma, c-myc rearrangement, Diffuse large B-cell lymphoma, Immunoglobulin heavy chain gene, Immunohistochemistry, MIB-1, Somatic mutation.

Mod Pathol 2002;15(7):771-776

Chromosomal translocations of 8q24, encoding an oncogene of c-myc, are considered to be associated with oncogênèsis of non-Hodgkin's lymphoma (NHL)/ (1-4). These chromosomal translocations dysregulate the expression of c- $m y c$, a gene encoding a basic helix-loop-helix (bHLH) transcription factor that binds to DNA in a sequence-specific fashion. c-Myc normally plays a central role in the transcriptional regulation of an emerging set of downstream genes that control diverse cellular processes, including cell cycle progression and programmed cell death (apoptosis). Translocation of $\mathrm{c}-m y c$ and immunoglobulin gene, $\mathrm{t}(8 ; 14)$ (q24;q32), $\mathrm{t}(2 ; 8)(\mathrm{p} 13 ; \mathrm{q} 24)$, and $\mathrm{t}(8 ; 22)(\mathrm{q} 24 ; \mathrm{q} 11)$ are observed in almost all Burkitt lymphomas (BLs), highly aggressive B-cell lymphomas. The histologic hallmark of BL is a monomorphic proliferation of mediumsized lymphoma cells with several small nucleoli and a starry-sky appearance $(5,6)$. The neoplastic cells usually express CD19, CD20, and CD10 $(5,6)$.

Although identification of c-myc rearrangement is prerequisite to a diagnosis of $\mathrm{BL}$, it is occasionally seen in other B-cell neoplasms, such as diffuse large B-cell lymphoma (DLBCL), lymphoblastic lymphoma (LBL), follicular lymphoma (FL), and multiple myeloma (MM) (7-14). Most cases of LBL, while showing a starry-sky appearance, can be easily distinguished from BL by their convoluted nuclei with 


\begin{tabular}{|c|c|c|c|c|c|c|c|c|c|c|c|c|c|c|c|}
\hline \multirow{2}{*}{$\begin{array}{l}\text { Case } \\
\text { No. }\end{array}$} & \multirow{2}{*}{$\begin{array}{l}\text { Age } \\
(\mathrm{y})\end{array}$} & \multirow[b]{2}{*}{ Gender } & \multirow{2}{*}{$\begin{array}{l}\text { Site of } \\
\text { Material }\end{array}$} & \multirow[b]{2}{*}{ Karyotype } & \multirow{2}{*}{$\begin{array}{l}\text { Southern } \\
\text { c-myc }\end{array}$} & \multicolumn{6}{|c|}{ Immunohistochemistry } & \multirow{2}{*}{$\begin{array}{c}\text { EBER-1 } \\
\text { RNA ISH }\end{array}$} & \multicolumn{2}{|c|}{ VH Somatic Mutation } & \multirow{2}{*}{$\begin{array}{c}\text { Prognosis } \\
\text { (mo) }\end{array}$} \\
\hline & & & & & & 20 & 3 & 10 & Bcl-6 & Bcl-2 & MIB-1 & & $\begin{array}{c}\text { Frequency } \\
(\%)\end{array}$ & $\begin{array}{c}\text { m./t. } \\
\text { (Germline) }\end{array}$ & \\
\hline \multicolumn{16}{|c|}{ Histologic BL group } \\
\hline 3 & 42 & $\mathrm{~F}$ & $\mathrm{LN}$ & NT & $\mathrm{R}$ & + & - & + & + & - & 99.3 & - & 4.9 & $\begin{array}{l}7 / 144 \\
\text { (DP48) }\end{array}$ & Alive (72) \\
\hline 4 & 4 & $\mathrm{~F}$ & Ovary & $\mathrm{t}(8 ; 14)$ & $\mathrm{R}$ & + & - & + & + & + & 95.9 & - & 2.7 & $\begin{array}{l}4 / 147 \\
\text { (DP 7) }\end{array}$ & Alive (59) \\
\hline 5 & 5 & M & LN & NT & $\mathrm{R}$ & + & - & + & + & - & 98.9 & - & 0.7 & $\begin{array}{l}1 / 144 \\
\text { (DP63) }\end{array}$ & Dead (8) \\
\hline 7 & 71 & M & Colon & $\mathrm{t}(8 ; 14)$ & NT & + & - & + & + & - & 98.9 & NT & & & Dead (4) \\
\hline 8 & 32 & $\mathrm{M}$ & Jejunum & $\mathrm{t}(8 ; 14)$ & NT & + & - & + & + & - & 98.3 & - & & & Dead (2) \\
\hline 9 & 4 & M & Omentum & $\mathrm{t}(8 ; 14)$ & NT & + & - & + & + & - & 98.8 & - & 2.8 & $\begin{array}{l}4 / 144 \\
\text { (DP63) }\end{array}$ & Dead (2) \\
\hline 10 & 7 & M & LN & $\mathrm{t}(8 ; 14)$ & NT & + & - & + & + & - & 98.6 & - & & & Dead (24) \\
\hline 11 & 42 & $\mathrm{~F}$ & $\mathrm{LN}$ & $\mathrm{t}(8 ; 14)$ & $\mathrm{R}$ & + & - & - & + & - & 98.9 & - & & & Unknown \\
\hline 15 & 7 & $\mathrm{M}$ & Ileum & $\mathrm{t}(8 ; 14)$ & NT & + & - & + & + & - & 98.9 & - & & & Unknown \\
\hline \multirow[t]{2}{*}{16} & 9 & M & Intestine & NT & $\mathrm{R}$ & + & - & + & + & NT & 94.7 & - & & & Alive (105) \\
\hline & & & & & Subtotal & $10 / 10$ & $0 / 10$ & $9 / 10$ & $10 / 10$ & $1 / 9$ & $\begin{array}{c}98.1 \\
\text { (average) }\end{array}$ & $0 / 9$ & $\begin{array}{c}2.3 \\
\text { (average) }\end{array}$ & & \\
\hline \multicolumn{16}{|c|}{ Histologic DLBCL group } \\
\hline 2 & 50 & $\mathrm{~F}$ & Soft tissue & NT & $\mathrm{R}$ & + & - & + & + & NT & 69.9 & - & 8.2 & $\begin{array}{l}12 / 147 \\
(\mathrm{DP} 35)\end{array}$ & Unknown \\
\hline 6 & 71 & $\mathrm{~F}$ & $\mathrm{BM}$ & $\mathrm{t}(8 ; 22)$ & NT & + & - & & & - & 61.3 & - & & & Alive (32) \\
\hline 12 & 58 & M & $\mathrm{LN}$ & $\mathrm{t}(8 ; 14)$ & $\mathrm{R}$ & + & & & & + & 89.7 & - & 32.0 & $\begin{array}{l}47 / 147 \\
(\mathrm{DP} 54)\end{array}$ & Unknown \\
\hline 13 & 74 & $\mathrm{~F}$ & $\mathrm{LN}$ & $\mathrm{t}(8 ; 14)$ & $\mathrm{R}$ & + & & & & & 48.0 & - & 10.9 & $\begin{array}{l}16 / 147 \\
(\mathrm{DP} 54)\end{array}$ & Dead (31) \\
\hline \multirow[t]{2}{*}{18} & 66 & M & LN & $\mathrm{t}(8 ; 14)$ & NT & + & - & & 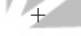 & + & 62.6 & - & & & Dead (45) \\
\hline & & & & & Subtotal & $5 / 5$ & $0 / 5$ & 15 & & & $\begin{array}{c}66.3 \\
\text { (average) }\end{array}$ & $0 / 5$ & $\begin{array}{c}17.0 \\
\text { (average) }\end{array}$ & & \\
\hline \multicolumn{16}{|c|}{ Histogically undetermined group } \\
\hline 1 & 81 & M & Skin & NT & $\mathrm{R}$ & + & - & + & + & & 98.4 & + & & & Unknown \\
\hline 14 & 66 & M & Stomach & $\mathrm{t}(8 ; 14)$ & NT & + & - & + & + & & 99.5 & - & & & Alive (39) \\
\hline \multirow[t]{2}{*}{17} & 28 & $\mathrm{M}$ & Stomach & $\mathrm{t}(8 ; 14)$ & NT & + & - & - & + & & 99.4 & - & & & Dead (3) \\
\hline & & & & & Subtotal & $3 / 3$ & $0 / 3$ & $2 / 3$ & $3 / 3$ & & & $1 / 3$ & & & \\
\hline
\end{tabular}

DLBCL, diffuse large B-cell lymphoma; LN, lymph node; BM, bone marrow; NT, not tested; R, rearrangement; +, positive; -, negative; BL, Burkitt's lymphoma; EBER, Esptein-Barr versus ER-1; m./t., mutation number/total nucleotide number; VH, immunoglobulin heavy chain gene variable region; ISH, in situ hybridization. Positive means that $>20 \%$-positive cells were immunostained by each antibody except MIB-1. (The percentages of cells positive for MIB-1 were estimated. The numbers of MIB-1-positive cells and all tumor cells were determined by an actual count in areas (2.5 mm $\left.{ }^{2}\right)$ counted at high-power field $(\times 400)$. Background small lymphocytes and starry sky macrophages were excluded. A mean of three areas in each case was taken as the MIB-1 index).

fine chromatin and detection of antigens such as TdT. FL and MM are different from BL in the cytologic features. However, DLBCL occasionally mimic BL. The neoplasms composed of medium-sized to large cells with a starry sky appearance and classified as small non-cleaved cell lymphoma, nonBurkitt in the Working Formulation (15) or as highgrade B-cell lymphoma, Burkitt-like (provisional entity) in the REAL (5) are difficult to differentiate from BL. In the new World Health Organization (WHO) classification, the gold standard for the diagnosis of BL should be the presence of $t(8 ; 14)$ (q24; q32) and its variants or c- myc rearrangement (6). If cytogenetic or Southern blot analysis is not available, BL should not be diagnosed without a Ki-67 fraction of close to $100 \%$ (6). DLBCLs with c-myc rearrangement, however, are known to account for $5-7 \%$ of DLBCL (10-12). What are differences between $\mathrm{BL}$ and DLBCL with $\mathrm{c}-m y c$ rearrangement $\left(\mathrm{c}-m y c^{\mathrm{R}} \mathrm{DLBCL}\right)$ ?

In this article, we analyzed clinical, histologic, immunohistochemical, and molecular features of 18 cases of B-cell NHL with c-myc rearrangement, to examine 1) the difference between $\mathrm{BL}$ and c- $m y c^{\mathrm{R}}$ DLBCL and 2) whether MIB-1 fraction of almost $100 \%$ is feature specific to BL. We found that c- $m y c^{\mathrm{R}}{ }^{\mathrm{DLBCL}}$ were clearly different from BL in term of immunoreactivity with CD10, Bcl-2, and MIB-1, as well as the frequency of somatic mutation of the immunoglobulin heavy chain $(\mathrm{IgH})$ gene variable region (VH gene).

\section{MATERIALS AND METHODS}

\section{Case Selection}

Eighteen cases of B-cell NHL with c-myc rearrangement detected by a cytogenetic analysis or Southern blotting were retrieved from the files of malignant lymphoma in six pathology departments. No cases associated with AIDS were included in this study.

\section{Histologic and Immunohistochemical Studies}

A part of resected tissue was fixed in $20 \%$ buffered formalin and embedded in paraffin for the routine 

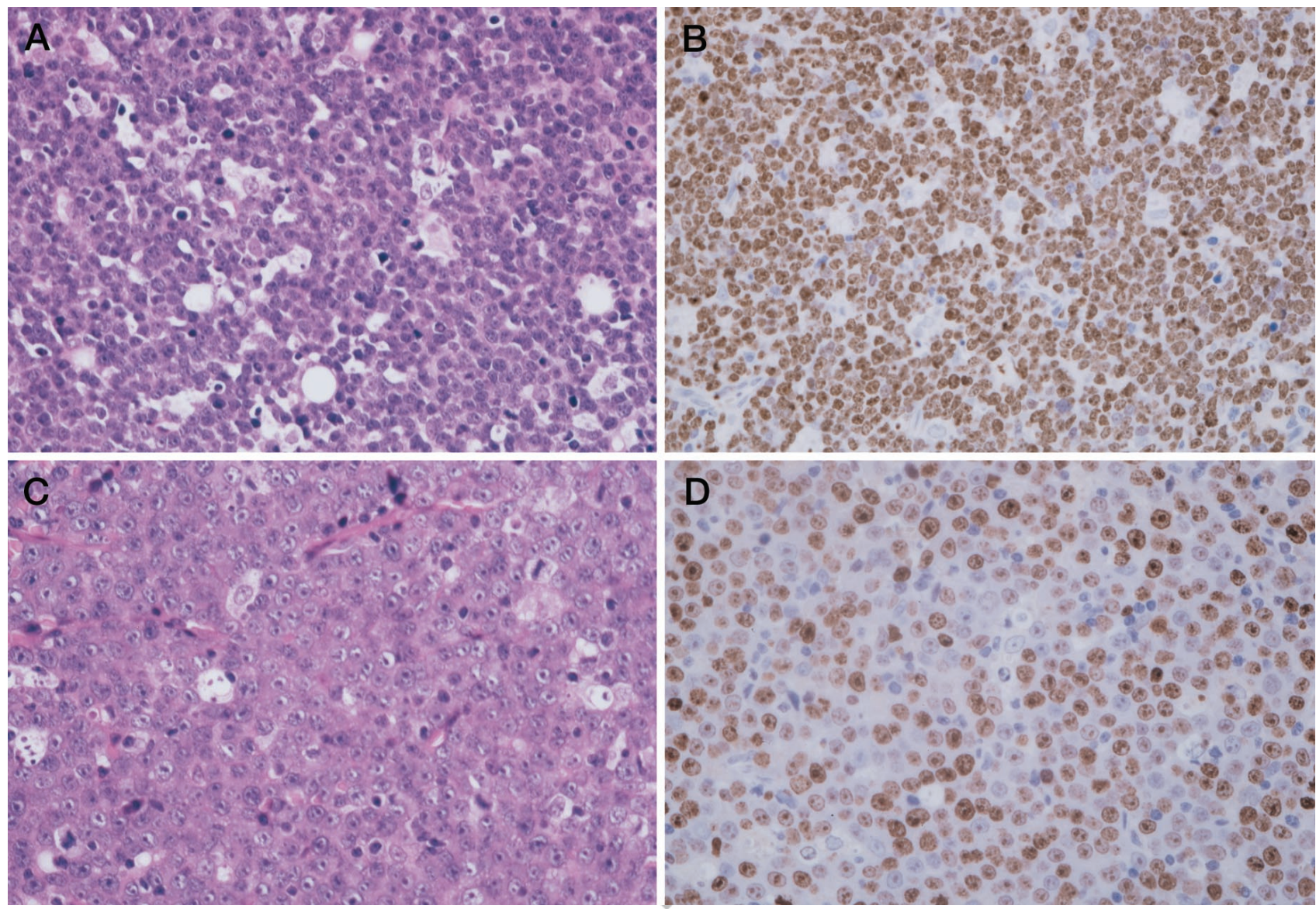

FIGURE 1. A, Burkitt lymphoma (Case 9). Hematoxylin-eosin stain. A medullary, cohesive and monotonous proliferation of medium-sized neoplastic cells is the histologic hallmark of Burkitt lymphoma. B, an immunoperoxidase stain for MIB-1. Almost all of the neoplastic cells are positive for MIB-1 (see Table 1). C, c- myc $c^{\mathrm{R}}$ DLBCL (Case 12); hematoxylin-eosin stain. A medullary proliferation of the large neoplastic cells with coarsely reticulated nuclear chromatin and centrally located prominent nucleoli are features of DLBCL, immunoblastic variant. D, an immunoperoxidase staining for MIB-1, MIB- $-1^{+}$tumor cells accounts for about $90 \%$ (see Table 1). Negatively stained large nuclei are occasionally seen.

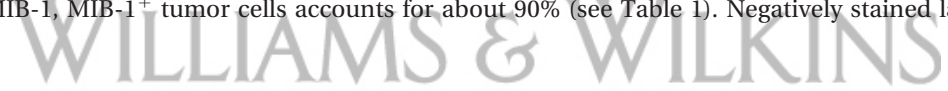

histologic and immunohistochemical studies. All cases were re-evaluated by all authors, and the histologic diagnosis was established according to the new WHO classification (6). Immunohistochemistry was performed on paraffin-embedded sections using the streptavidin-biotin complex technique (16). Monoclonal and polyclonal antibodies used in this study were as follows: CD3 (CD3 $\epsilon$, DAKOPATTS[DA], DAKO, Glostrup, Denmark), CD10 (CD10, Novocastra Laboratories Ltd. [NC], Newcastle Upon Tyne, UK), CD20 (L26, DA), Bcl-6 (Santa Cruz, CA), Bcl-2 (Bcl-2, DA) and MIB-1 (MIB-1, DA). A given lymphoma was judged positive when $>20 \%$-positive cells were immunostained by each antibody except MIB-1. The percentages of positive cells for MIB-1 were estimated. The numbers of MIB-1 positive cells and all tumor cells were determined by an actual count in areas $\left(2.5 \mathrm{~mm}^{2}\right)$ counted at high-power field $(400 \times)$. Background small lymphocytes and starry-sky macrophages were excluded. A mean of three areas in each case was taken as the MIB-1 index.

\section{Molecular Studies}

Epstein-Barr virus RNA in situ hybridization

Epstein-Barr (EB) virus RNA in situ hybridization (EBER-1 RNA-ISH) was performed as described elsewhere for detection of the genome of EBV (17).

\section{Somatic mutation of the IgH gene variable region}

The IgH gene was amplified by semi-nested PCR, according to a method described elsewhere (18), and variable region (CDR2 and FW3) was analyzed.

\section{RESULTS}

Clinical, histologic, immunohistochemical, and molecular data are shown in Table 1. The patients were distributed in age from 4 to 81 years old, with a male to female ratio of 12:6. Eleven cases presented with extranodal lymphoma, whereas seven had nodal lymphoma. Cytogenetic data was available in 13 cases. Twelve cases carried $\mathrm{t}(8 ; 14)$ (q24; q32) and one case $\mathrm{t}(8 ; 22)(\mathrm{q} 24 ; \mathrm{q} 11)$, and karyotypes 


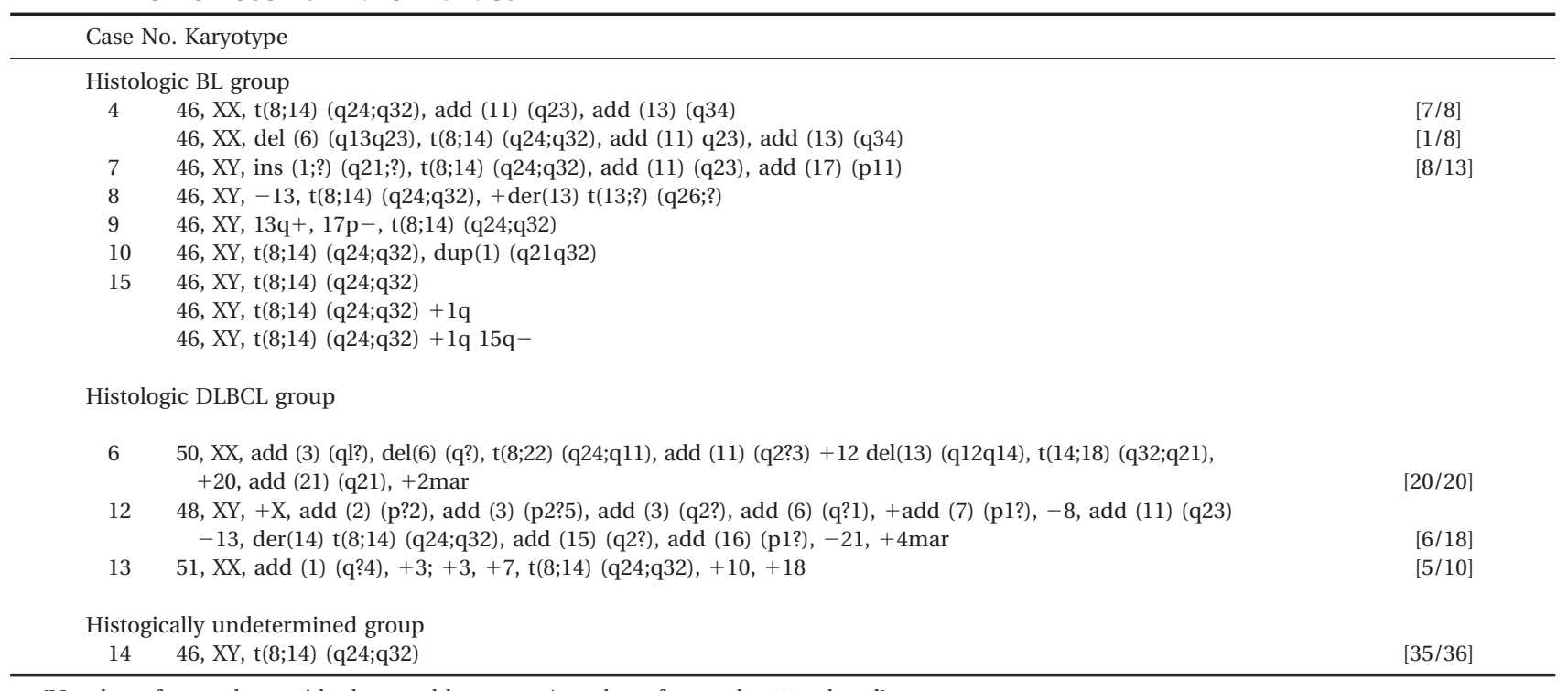

[Number of metaphase with abnormal karyotype/number of metaphase analyzed]

of 10 cases are shown in Table 2. c-Myc rearrangements were found in nine cases by Southern blotting analysis.

A consensus diagnosis by re-evaluation of routine HE section of all 18 cases among all authors is shown in Table 1 . Ten cases were diagnosed as BL, whereas five cases were diagnosed as DLBCL. Because consensus diagnoses could not be obtained because of suboptimal quality of materials available, the remaining three cases were put into an undetermined group. The BL group consisted of children and adults, whereas the DLBCL group consisted of adults only.

Results of immunohistochemical study and EBER-1 RNA-ISH are shown in Table 1. BLs represented 10 positive cases/10 examined cases for CD20, 0/10 for CD3, 9/10 for CD10, 10/10 for Bcl-6, $1 / 9$ for Bcl-2, and 0/8 for EBV. DLBCLs represented 5/5 for CD20, $0 / 5$ for CD3, $2 / 5$ for CD10, $4 / 4$ for Bcl-6, 3/4 for Bcl-2, and 0/5 for EBV. The undetermined group represented $3 / 3$ for $C D 20,0 / 3$ for CD3, $2 / 3$ for CD10, $3 / 3$ for Bcl-6, 0/3 for Bcl-2, and $1 / 3$ for EBV. The Bcl-2 expression differed between BLs (1/9) and DLBCLs (3/4). There was no statistically significant difference between them $\left(\chi^{2}\right.$-test $)$. The MIB-1 index of BLs and DLBCLs were distributed from 94.7 to $99.3 \%$, with a mean of $98.1 \%$ and from 48.0 to $89.7 \%$ with a mean of $66.3 \%$, respectively. There was a statistically significant difference between them ( $t$ test, $P<.0001$ ). [Fig. 1]

Frequency of somatic mutation of the VH gene in the BL group (four cases) ranged from 0.7 to $4.9 \%$, with an average of $2.3 \%$, whereas that in the DLBCL group (three cases) ranged from 8.2 to $32.0 \%$, with an average of $17.0 \%$. (Table 1) The average of somatic mutation frequency in the DLBCL group was higher than that in the BL group, but there was no statistical difference between them ( $t$ test, $P=$ .0793).

\section{DISCUSSION}

To compare clinicopathologic features of BL with those of $\mathrm{c}-m y c^{\mathrm{R}}$ DLBCL, we analyzed 18 cases of B-cell lymphoma with c-myc rearrangements. Except for three cases with suboptimal specimens, we reached a consensus diagnosis of either BL or DLBCL in all 15 cases. Because we failed to obtain a consensus diagnosis in several cases using the REAL classification, the description in the new WHO classification can give more reproducible pathologic criteria for the differentiation between BL and DLBCL.

Although the translocation of c-myc and Ig genes is the gold standard for BL, we demonstrated some differences between BLs and c- $m y c^{\mathrm{R}}$ DLBCL. $\mathrm{CD}_{10}{ }^{+}, \mathrm{Bcl}-2^{-}$, and extremely high rate of $\mathrm{MIB}-1^{+}$ cells were characteristic for BL. The mean MIB-1 index in BLs was $98.1 \%$, and the indices generally were $>98 \%$, except in two cases. A growth fraction of nearly $100 \%$ can be expected for BLs. In c- $m y c^{\mathrm{R}}$ DLBCLs, on the contrary, MIB-1 index was distributed from 48.0 to $89.7 \%$, and the mean $(66.3 \%)$ was lower than that of BLs. More than 95\% of MIB-1 expression was not seen in any of the five cases of $c-m y c^{R}$ DLBCL. Degree of the MIB-1 expression varied from case to case and were not clearly different from DLBCL without c-myc rearrangement (data not shown). As Bcl-2 was previously reported to be negative for BL (19), Bcl-2 did not react with all cases of BL but one. An absence of Bcl-2 protein, as well as extremely high rate of the MIB-1 index is a good marker for BL. 
EBV was not detected by EBER-1 RNA-ISH in both BL and c- $m y c^{\mathrm{R}}$ DLBCL, but chromosomal abnormalities of $c-m y c^{\mathrm{R}}$ DLBCL were more complex, with many losses and gains involving chromosomes other than those in BL. Because breakpoints at c-myc and Ig genes have been reported to be similar in both $\mathrm{BL}$ and $\mathrm{c}-m y c^{\mathrm{R}}$ DLBCL by the long-distance PCR and cloning analyses (12), the hypothesis could be raised that both lymphomas are the same disease, showing different stages of tumor progression. This hypothesis, however, seems unlikely because of the following reasons. Both of $\mathrm{BL}$ and DLBCL are considered to be derived from germinal center (GC) B cells because of the expression of Bcl-6 and high frequency of somatic mutation of the rearranged $\mathrm{VH}$ genes (20-23). Somatic mutation frequencies of the $\mathrm{VH}$ gene of the endemic and sporadic BLs are reported to have ranges between $5-15 \%$ and $0-5 \%$, respectively (24). In our series, the $\mathrm{VH}$ gene of $\mathrm{BL}$ was somatically mutated in a range of $0-5 \%$ with an average of $2.3 \%$. On the other hand, two of three cases of $c-m y c^{\mathrm{R}}$ DLBCL examined revealed $>10 \%$ of mutation frequency in rearranged $\mathrm{VH}$ gene. We previously reported an average of $11.9 \%$ of mutation frequency, with a broad range, in 60 cases of $\mathrm{EBV}^{-}$DLBCL (25), and this pattern is similar to that of $\mathrm{c}-m y c^{\mathrm{R}}$ DLBCL. Moreover, using additional cases, we have found a statistical difference in somatic mutation rates between BLs and c- $m y c^{\mathrm{R}}$ DLBCLs (unpublished data, in preparation).

c- $M y c^{\mathrm{R}}$ DLBCL is known to occasionally involve the coexistence of $\mathrm{t}(14 ; 18)$ involving $\mid b c l-2$ genes (26). Dual translocation of $c-m y c$ and $b c l$-2 is characterized by a rapid clinical course and extremely poor outcome, and some cases with dual translocation of c- $m y c$ and $b c l-2$ are regarded as instances of transformation of follicular lymphoma. There were no cases with dual translocation of $\mathrm{c}-m y c$ and $b c l-2$ in our series.

BL accounts for $1-2 \%$ of total NHLs $(27,28)$, and most of them are of a sporadic type in non-African areas. Because c- $m y c$ rearrangement is found in $5-7 \%$ of DLBCL, which account for $30 \%$ of total NHLs, c- $m y c^{\mathrm{R}}$ DLBCL is estimated to constitute 1.5$2.1 \%$ of total NHL. The similar frequency of BL and $\mathrm{c}-m y c^{\mathrm{R}}$ DLBCL indicates that the rearrangement may occur in various GC stages in secondary B-cell differentiation. When the neoplastic proliferation is initiated by c- $m y c /$ Ig translocation at a given stage of the secondary B-cell differentiation in the GC, it is not likely that clinically and histologically distinct neoplasms, that is, BL and DLBCL, arise. It is, therefore, indicated that the normal counterparts of $\mathrm{BL}$ and $c-m y c^{\mathrm{R}}$ DLBCL are different.

Although BL has aggressive clinical course and results in poor outcome, this tumor is highly sensitive to chemotherapeutic regimens, and the response is dif- ferent from that of other aggressive B-cell lymphomas $(3,27)$. Five of eight patients with BL in this series had a poor prognosis, and a majority of them died of disease within 1 year. Although the clinical outcome of two patients was unknown in our series, Vitolo et al. (10) analyzed 71 cases with DLBCL including four cases of c- $m y c^{\mathrm{R}}$ DLBCL. All cases were treated with an anthracycline-containing chemotherapy regimen. These four patients with c- $m y c^{\mathrm{R}}$ DLBCL had an aggressive disease with poor prognosis. Kramer et al. (11) reported that structural alterations of c- myc were detected in 10 of 151 cases of DLBCL by Southern blot analysis (6.7\%), and two of them had both $b c l-6$ and c-myc rearrangements. In their series, c-myc rearrangements were found in $16 \%$ of primary extranodal lymphomas, whereas only $2 \%$ of primary nodal cases had these abnormalities $(P=.02)$. In particular, 5 of 18 cases $(28 \%)$ of gastrointestinal lymphomas had the c- $m y c$ rearrangements. Seven of ten cases with c-myc rearrangements achieved a complete remission and six responders remained alive for $>4$ years, resulting in the trend of a better disease-free survival. Thus, our speculation that the normal counterparts of BL and c- $m y c^{\mathrm{R}}$ DLBCL are different can be clinically supported.

Acknowledgments: The authors thank Prof. Dr. Masahiro Kikuchi, Fukuoka University, and Dr. Masao Seto, Aichi Cancer Center, for their excellent advice.

\section{References KINS}

1. Magrath IT. African Burkitt's lymphoma: history, biology, clinical features, and treatment. Am J Pediatr Hematol Oncol 1991;13:222-46.

2. Hecht JL, Aster JC. Molecular biology of Burkitt's lymphoma. J Clin Oncol 2000;18:3707-21.

3. Dalla-Favera R, Bregni M, Erikson J, Patterson D, Gallo RC, Croce CM. Human c-myc oncogene is located on the region of chromosome 8 that is translocated in Burkitt lymphoma cells. Proc Natl Acad Sci U S A 1982;79:7824-7.

4. Taub R, Kirsch I, Morton C, Lenoir G, Swan D, Tronick S, et $a l$. Translocation of the c-myc gene into the immunoglobulin heavy chain locus in human Burkitt lymphoma and murine plasmacytoma cells. Proc Natl Acad Sci U S A 1982;79:783741.

5. Harris NL, Jaffe ES, Stein H, Banks PM, Chan J, Cleary ML, et $a l$. A revised European-American classification of lymphoid neoplasms: a proposal from the International Lymphoma Study Group. Blood 1994;84:1361-92.

6. Diebold J, Jaffe ES, Raphael M, Warnke RA. Burkitt lymphoma. In: Jaffe ES, Harris NL, Stein H, Vardiman JW, editors. World Health Organization classification of tumours. Tumours of haematopoietic and lymphoid tissues. Lyon, France: IARC Press; 2001: p. 181-4.

7. Sigaux F, Berger R, Bernheim A, Valensi F, Daniel MT, Flandrin G. Malignant lymphomas with band 8q24 chromosome abnormality: a morphologic continuum extending from Burkitt's to immunoblastic lymphoma. Br J Haematol 1984;57:393-405. 
8. Slavutsky I, Andreoli G, Gutierrez M, Narbaitz M, Lucero G, Eppinger M. Variant $(8 ; 22)$ translocation in lymphoblastic lymphoma. Leuk Lymphoma 1996;21:169-72.

9. Macpherson N, Lesack D, Klasa R, Horsman D, Connors JM, Barnett M, et al. Small noncleaved, non-Burkitt's (BurkittLike) lymphoma: cytogenetics predict outcome and reflect clinical presentation. J Clin Oncol 1999;17:1558-67.

10. Vitolo U, Gaidano G, Botto B, Volpe G, Audisio E, Bertini M, et al. Rearrangements of bcl-6, bcl-2, c- myc and 6q deletion in B-diffuse large-cell lymphoma: clinical relevance in 71 patients. Ann Oncol 1998;9:55-61.

11. Kramer MH, Hermans J, Wijburg E, Philippo K, Geelen E, van Krieken JH, et al. Clinical relevance of BCL2, BCL6, and MYC rearrangements in diffuse large B-cell lymphoma. Blood 1998;92:3152-62.

12. Akasaka T, Akasaka H, Ueda C, Yonetani N, Maesako Y, Shimizu A, et al. Molecular and clinical features of nonBurkitt's, diffuse large-cell lymphoma of B-cell type associated with the c-myc/immunoglobulin heavy-chain fusion gene. J Clin Oncol 2000;18:510-8.

13. Sawyer JR, Waldron JA, Jagannath S, Barlogie B. Cytogenetic findings in 200 patients with multiple myeloma. Cancer Genet Cytogenet 1995;82:41-9.

14. Shou Y, Martelli ML, Gabrea A, Qi Y, Brents LA, Roschke A, et $a l$. Diverse karyotypic abnormalities of the c-myc locus associated with c-myc dysregulation and tumor progression in multiple myeloma. Proc Natl Acad Sci U S A 2000;97:228-33.

15. National Cancer Institute sponsored study of classifications of non-Hodgkin's lymphomas: summary and description of a working formulation for clinical usage. The Non-Hodgkin's Lymphoma Pathologic Classification Project. Cancer 1982; 49:2112-35.

16. Hsu SM, Raine L, Fanger H. Use of avidin-biotin-peroxidase complex (ABC) in immunoperoxidase techniques: a comparison between $\mathrm{ABC}$ and unlabeled antibody (PAP) procedures. J Histochem Cytochem 1981;29:577-80.

17. Kuze T, Nakamura N, Hashimoto Y, Abe M, Wakasa $\mathrm{H}$. Clinicopathological, immunological and genetic studies of $\mathrm{CD} 30+$ anaplastic large cell lymphoma of B-cell type; association with Epstein-Barr virus in a Japanese population. J Pathol 1996;180:236-42.

18. Nakamura N, Hashimoto Y, Kuze T, Tasaki K, Sasaki Y, Sato $\mathrm{M}$, et al. Analysis of the immunoglobulin heavy chain gene variable region of CD5-positve diffuse large B-cell lymphoma. Lab Invest 1999;79:925-33.

19. Lai R, Arber DA, Chang KL, Wilson CS, Weiss LM. Frequency of bcl-2 expression in non-Hodgkin's lymphoma: a study of 778 cases with comparison of marginal zone lymphoma and monocytoid B-cell hyperplasia. Mod Pathol 1998;11:864-9.

20. Tamaru J, Hummel M, Marafioti T, Kalvelage B, Leoncini L, Minacci C, et al. Burkitt's lymphomas express VH genes with a moderate number of antigen-selected somatic mutations. Am J Pathol 1995;147:1398-407.

21. Chapman CJ, Zhou JX, Gregory C, Rickinson AB, Stevenson FK. VH and VL gene analysis in sporadic Burkitt's lymphoma shows somatic hypermutation, intraclonal heterogeneity, and a role for antigen selection. Blood 1996;88:3562-8.

22. Jain R, Roncella S, Hashimoto S, Carbone A, Francia di Celle $\mathrm{P}$, Foa R, et al. A potential role for antigen selection in the clonal evolution of Burkitt's lymphoma. J Immunol 1994; 153:45-52.

23. Müller-Hermelink HK, Greiner A. Molecular analysis of human immunoglobulin heavy chain variable gene $(\mathrm{IgVH})$ in normal and malignant B cells. Am J Pathol 1998;153:1341-5.

24. Klein U, Goossens T, Fischer M, Kanzler H, Braeuninger A, Rajewsky $\mathrm{K}$, et al. Somatic hypermutation in normal and transformed human B cells. Immunol Rev 1998;162:26180.

25. Kuze T, Nakamura N, Hashimoto Y, Sasaki Y, Abe M. The characteristics of Epstein-Barr virus (EBV)- positive diffuse large B-cell lymphoma: comparison between $\mathrm{EBV}^{+}$and $\mathrm{EBV}^{-}$cases in Japanese population. Jpn J Cancer Res 2000; 91:1233-40.

26. Macpherson N, Lesack D, Klasa R, Horsman D, Connors JM, Barnett M, et al. Small noncleaved, non-Burkitt's (Burkittlike) lymphoma: cytogenetics predict outcome and reflect clinical presentation. J Clin Oncol 1999;17:1558-67.

27. The Non-Hodgkin's Lymphoma Classification Project. A clinical evaluation of the international lymphoma study group classification of non-Hodgkin's lymphoma. Blood 1997;89:3909-18.

28. Lymphoma Study Group of Japanese Pathologists. The World Health Organization classification of malignant lymphomas in Japan: incidence of recently recognized entities. Pathol Int 2000;50:696-702. 